\title{
THE CORRELATION BETWEEN VOCABULARY MASTERY AND STUDENTS' ACHIEVEMENT IN WRITING DESCRIPTIVE TEXT AT THE EIGHTH GRADERS OF SMP NEGERI 3 KOTABUMI IN ACADEMIC YEAR 2020/2021
}

\author{
${ }^{1}$ Usi Ismayanti, ${ }^{2}$ Rini Susilowati \\ usiismayantii1@gmail.com, Rini.ariyanto12@gmail.com
}

Universitas Muhammadiyah Kotabumi

\begin{abstract}
This research was aimed to find out whether there is correlation between vocabulary mastery and students' achievement in writing descriptive text. The objective of this research was to investigate whether there is significant correlation between vocabulary mastery and students' achievement in writing descriptive text at the eighth graders of SMP Negeri 3 Kotabumi in academic year 2020/2021. The kind of the research was quantitative research and used correlational research design. The sample of the research were 40 students which were taken by using proportional random sampling technique. The instruments used in this research were tests and divided into two types of test. The first test was written test and the second test was vocabulary mastery test with multiple choice form. Then, to prove the hypothesis of the research, the researcher analyzed the data by using the formula of Pearson product moment correlation and resulted $r_{\text {observed }} 0,977 \geq r_{\text {table }} 0,312$. Then, resulted $t_{\text {observed }} 28,24 \geq t_{\text {table }}$ 2,027 . Based on the result of the data analysis above, it can be concluded that Ha is accepted and $\mathrm{H} 0$ is rejected, which showed there is significant correlation between vocabulary mastery and the students' achievement in writing descriptive text at the eighth graders of SMP Negeri 3 Kotabumi in academic year 2020/2021.
\end{abstract}

Keywords: Vocabulary Mastery, Writing Achievement, Descriptive Text.

Abstrak: Penelitian ini bermaksud untuk menyelidiki fenomena tentang penguasaan kosakata siswa yang dapat berhubungan dengan pencapaian menulis mereka. Tujuan dari penelitian ini adalah untuk menginvestigasi apakah ada korelasi yang signifikan antara penguasaan kosa kata dan pencapaian siswa dalam menulis teks dekskriptif pada siswa kelas delapan SMP Negeri 3 Kotabumi tahun akademik 2020/2021. Jenis penelitian ini adalah penelitian kuantitatif dan menggunakan model penelitian korelasi. Penelitian ini diikuti oleh 40 siswa yang telah ditetapkan dengan teknik proportional random sampling. Instrumen yang digunakan pada penelitian ini adalah test dan dibagi menjadi dua tipe test. Test pertama merupakan test menulis dan test kedua merupakan test penguasaan kosakata dengan bentuk pilihan ganda. Lalu, untuk membuktikan hipotesis penelitian, peneliti menganalisis data menggunakan rumus pearson product moment correlation dan menghasilkan nilai $r_{\text {hitung }}=$ 0,977. Lalu, $t_{\text {hitung }} \geq t_{\text {tabel }}$, dengan nilai $t_{\text {hitung }}$ sebesar 28,24 dan $t_{\text {tabel }}$ sebesar 2,027. Berdasarkan hasil dari analisis data diatas, dapat disimpulkan bahwa Ha diterima dan HO ditolak, yang menunjukan ada korelasi yang signifikan antara penguasaan kosa kata dan pencapaian siswa dalam menulis teks dekskriptif pada siswa kelas delapan SMP Negeri 3 Kotabumi tahun akademik 2020/2021.

Kata Kunci: Penguasaan Kosakata, Pencapaian Menulis, Teks Dekskriptif.

${ }^{1}$ Mahasiswa Universitas Muhammadiyah Kotabumi

${ }^{2}$ Dosen Universitas Muhammadiyah Kotabumi 


\section{INTRODUCTION}

Among the four language skills, writing have their own difficulty. Therefore, this skill is taught gradually at the school. In junior high school especially in English language learning the students should be able to write some English text which one of them is descriptive text. However, writing become the hardest skill which is not easy to be mastered by students because in the process of writing itself it requires a creative thinking and more knowledge about how to arrange an idea in the written form by paying attention to several language aspects such as vocabulary, grammar, diction, punctuation, spelling and structures to make good sentences which are appropriate with the context.

Talking about the difficulty in writing process, there are a lot of problems that makes this activity is not easy to be mastered by the students. According to Hidayati (2018, p. 25) writing is challenging activity. There are some factors that make students had difficulties in writing process, including less of motivation and difficulties in linguistic competence such as lack of grammar and vocabulary mastery.

Regarding to the research finding above, those problems also happened in SMP Negeri 3 Kotabumi. Based on the interview done with the English teacher of the eighth grade in SMP Negeri 3 Kotabumi. It was known that the students faced some problems during the learning process of writing that make the students hard to finish the writing task given. Some problems which seemed to be experienced by the students were they have difficulties to arrange the sentence correctly in writing a certain type of text in English, lack of vocabulary, they were not be able to choose vocabulary appropriately, and they have less motivation to practice. As a result they often had difficulty and obstacle in pouring their idea into good writing.

From the explanation of the problems above, it is clear that most of the students in SMP Negeri 3 Kotabumi still have difficulties in writing process in which one of them was caused by their lack of vocabulary mastery. Because of that reason, there was assumption that vocabulary mastery become one of the most important aspects that need to be noticed in writing process. As stated by Renandaya (as cited in Hasan and Subekti, 2017, p. 56) vocabulary is a fundamental component of language. In other words, vocabulary played important role in writing process. It can be assumed that the more vocabularies the students know the better their opportunity to do well and write easily. Therefore, the way the students produce their writing effectively can be influenced by the use of appropriate vocabulary.

Referring to the explanation about the importance of mastering vocabulary in the 
process of writing a descriptive text, the researcher was interested in conducting a correlational research in order to investigate whether there is significant correlation between vocabulary mastery and students' writing achievement in terms of descriptive text and proved the theory related the importance of vocabulary mastery in writing process. Therefore, the researcher was conducted a research with the title "The Correlation between Vocabulary Mastery and Students' Achievement in Writing Descriptive Text at the Eighth Graders of SMP Negeri 3 Kotabumi in Academic Year 2020/2021."

\section{LITERATURE REVIEW}

\section{Concept of Writing Ability}

Writing is a process to deliver someone's feelings, arguments and ideas that is felt by the writer into the paper by constructing the words. It can be used as media to communicate with others through written form. Many experts have argued about the definition of writing. Wingersky (as cited in Hidayati, 2018, p. 23) states, "writing is a process of communicating with others in which the writers send his ideas and thoughts in written form to the readers". In this case, the writers should produce a sequence of sentences and clear statement to make the readers understand the meaning what the writer wants to say. From the explanation above, it can be concluded that writing is a process delivering an idea, imagination and feeling which are developed by using sentences which describe the meaning of writer wants to convey through complex process.

Besides that, writing related with the ability. Hornby (2010, p. 2) states that ability is a level of skill or power that is had by people. In conclusion, writing ability can be asummed as the ability had by students to write some texts in English which required a writer to be able to use language patterns to express an idea which aims to make other people who read the text can understand the ideas conveyed.

\section{Writing Assessment}

The assessment on writing achievement is to determine how good the writing of the students is. It is to measure the degree of students' writing achievement. The teacher provide a test to assess how the students write and organize their ideas into good writing effectively. The teacher as a guide and evaluator in teaching and learning process should have an appropriate and right concept of writing assessment to be able assessed the writing work of students. 
Generally, the grade of writing skill is taken from criteria of writing test. According to Brown (2004, p. 244-245) there are five categories that must be assessed in writing. The categories are organization, content, grammar, mechanics, and style quality of expressions. In every categories, commonly the students will get 20 score as the highest score and 1 score as the lowest score. Therefore, the teacher must consider those categories carefully in assessing the students' writing test result.

\section{Concept of Achievement}

The terms of achievement have several meaning. Longman (2001, p. 11) revealed that achievement is a success thing that is got by someone in doing something by his or her own efforts. In addition, Levpuscek (as cited in Riswanto and Aryani, 2017, p. 43) explain that students' achievement can be described as a level of the students to achieve the learning goals in terms of knowledge and skills. It means that students' achievement reflects the quality of education and learning process and shows how well the students achieve the learning goals.

From the theories above, it can be concluded that achievement concerned with the result of learning activities that has been done and obtained by efforts. Meanwhile, talking about the achievement in writing, it can be defined as the students' mastery in constructing the words into the sentences with well structures and make a good text that suitable with the topic. In this case, the students are not only can write a text but also get high score in writing test. The teacher can see the ability of students in mastering the writing skill that has been taught by looking at the result of students' score in writing test.

\section{Concept of Descriptive Text}

Wyrick (as cited in Husna et.al, 2013, p. 2) explained that in writing descriptive text the writer creates a detail picture of person, place, object and emotion to make an impression to the reader. It can be assumed that descriptive text is a piece of writing and one of the kind text which describes the qualities, part and characteristics of an object. In the process of writing descriptive text there are several things which must be considered. Pardiyono (2006, p. 166) emphasize that descriptive text have two generic structures, they are identification and description Identification explains the introduction of the object that will be described briefly and description explains clearly the object that will be described.

Referring to the theories above, it can be concluded that descriptive text is a kind of text which describe about specific object, 
thing and place in detail and contains several things that must be considered in the process of writing the text. The goal in making a descriptive text is to provide information about the thing, object or a person which is described.

\section{Concept of Vocabulary Mastery}

The term of vocabulary has wide meaning. In short, vocabulary can be defined as a set of words that have meaning. Ur (2009, p. 60) revealed that vocabulary is the words which are taught in the foreign language, it can be a single words or more than single words. Additionally, Porter (2001, p. 953) emphasized that mastery is the ability owned by someone in understanding something completely and do not have difficulty in using it.

From explanation above of the experts above, it can be concluded that vocabulary mastery can be defined as students' ability in understanding all English words that they have learned in certain situation, obtained through long process and a lot practice.

\section{The Role of Vocabulary in Writing}

In some ways, the ability to write well and effectively is obtained by having a lot of vocabularies. During writing process, vocabulary becomes the most important aspect that should be mastered by students. According to Cameron (as cited in Susilowati, 2018, p. 38) vocabulary plays a great role for learners in acquiring a language. In line with Cameron, Thornburry (as cited in Setiani, 2018, p. 34) states, "without mastery the grammar in writing process very little can be conveyed. However, without vocabulary nothing can be conveyed."

From the explanantion above, it can be concluded that, vocabulary is the most important aspect that will be mastered first before the students wants to write something. They cannot produce a good writing text if they do not know the vocabulary that they want to use in arranging their ideas in the written form because in writing process the students have to possess huge word power to be able produce a good writing.

\section{RESEARCH METHODS}

This research was quantitative research and used correlational research design. Creswell (2012, p. 338) states that correlational research design provide an opportunity to the researcher to be able to describe and measure the degree of relationship between two variables or more. It is used to know whether the variables have 
correlation or not and also get empirical evidence about the direct relationship between $\mathrm{X}$ variable and $\mathrm{Y}$ variable without giving any treatment. The $\mathrm{X}$ variable of the research is vocabulary mastery which is called as independent variable and $\mathrm{Y}$ variable is students' achievement in writing descriptive test which is called as dependent variable.

This research was conducted at the eighth graders of SMP Negeri 3 Kotabumi with total of population consist of 256 students. Then, the sample of the research consist of 40 students which was established by using proportional random sampling technique.

Before doing a research and took the data, it is important to measure the validity and the reliability of the instrument that used in the research. In this case, the researcher did a try out to be able to measure the validity and the reliability of the instrument. In addition, to measure the validity of the instruments, the researcher used the formula of point biserial for vocabulary mastery instrument and construct validity for writing instrument. Meanwhile, to measure the reliability of the instrument of vocabulary mastery, the researcher used the formula of kuder-richardson and inter-rater reliability for writing instument.

Additionally, after measuring the validity and the reliability of the instrument and resulted that both of the instrument were valid and reliable. It was continued by doing a real research in SMP Negeri 3 Kotabumi. The research was conducted by online through Google Formulir and divided into two sessions. The first session was writing test and the second session was vocabulary mastery test. Then, the result of the students in writing test and vocabulary mastery test were analyzed into four steps. The steps were normality test, homogeneity test, hypothesis test and significant test.

All those steps above was done to be able to find out the correlation between vocabulary mastery and students' achievement in writing descriptive text at the eighth graders of SMP Negeri 3 Kotabumi in academic year 2020/2021.

\section{RESEARCH RESULT}

This research was started by conducting a try out first before doing the real research. The try out was done at the eighth graders of SMP Negeri 7 Kotabumi followed by 30 students. It was done to be able to know the validity and the reliability of both instruments that used in the research.

In accordance with the result calculation of validity test for vocabulary mastery instrument by using the formula of point biserial. It was found that there were 20 items were valid from 40 total items of the test. It shows that those 20 items were proper to be used in the real research. The 
summary of the valid and invalid items of the test were described in the following table below:

\section{Table 1}

Summary of Validity

Test Result of Vocabulary Mastery

\begin{tabular}{|c|c|}
\hline \multicolumn{2}{|c|}{ Vocabulary Mastery } \\
\hline Valid Items & $\begin{array}{l}8,10,11,12,14,15, \\
16,19,20,21,22, \\
24,28,31,32,33, \\
35,36,38,39 .\end{array}$ \\
\hline Invalid Items & $\begin{array}{l}1,2,3,4,5,6,7,9, \\
13,17,18,23,25, \\
26,27,29,30,34, \\
37,40 .\end{array}$ \\
\hline Total Items & 40 \\
\hline
\end{tabular}

Meanwhile, to measure the validity of writing instrument, the researcher used construct validity. To get construct validity of the instrument, the researcher used opinion from the experts or usually called as the expert judgment. In this case, after the experts analyzed the instrument and gave a little critics and suggestion. Then, the researcher revised the instrument has been made by the researcher, they concluded that the instrument was valid in term of construct validity. Therefore, the instrument can be used in the research.

After analyzing the validity for both instruments, it was continued by measuring the reliability of the vocabulary mastery and writing instrument. In measuring the reliability of vocabulary mastery instrument, the researcher used the formula of Kuder Richardson-20. In addition, the reliability of writing instrument was found by using the formula of inter-rater reliability. The summary of the reliability calculation for both of the instruments, can be seen as follows:

Table 2

Summary of Reliability Test

\begin{tabular}{|c|c|}
\hline Type of instrument & Result \\
\hline $\begin{array}{c}\text { Vocabulary Mastery } \\
\text { Instrument }\end{array}$ & 0,821 \\
\hline Writing Instrument & 0,973 \\
\hline Description & Reliable \\
\hline
\end{tabular}

From the result of the calculation, the coefficient reliability of vocabulary mastery instrument and writing instrument was higher than 0,70. As stated by Litwin (as cited in khumaedi, 2012, p. 29) the instrument can be said reliable if the value is about 0,70 or more. Therefore, those two instruments can be categorized reliable because the value of $r$ more than 0,70 .

Based on the result of validity and reliability of the vocabulary mastery and writing instrument above, it could be said that those two instruments were proper to be used by the researcher to collect the data of 
the research because the instrument of the research was reliable or consistent and had valid question.

In this research, after the researcher conducted the try out and analyzed it, then the researcher began to conduct a research in order to collect the data of the research. The test was conducted at the eighth graders of SMP Negeri 3 Kotabumi on Monday, January $18^{\text {th }} 2021$ followed by 40 students. The test were consisted of two kinds of test and divided into two sessions. The first session, the students worked on the vocabulary mastery test with multiple choice form that consist of 20 questions. Then, in the second session, the students worked on the written test, in which the students were asked to write a descriptive text based on the topic that they was chosen.

After all the test had done completely, the result of the students' score have been analyzed by the researcher. In analyzing the data that have been gotten from the test, the researcher used four steps. The first step was normality test that used to know whether the data were normally distributed or not. The second step was homogeneity test that used to know whether the population of the research were homogeneous or not. The third step was hypothesis test that used to determine the correlation between two variables and proved the research hypothesis. The last step was significant test that used to know how far the significance of the correlation among vocabulary mastery and students' achievement in writing descriptive text.

In this research, testing the normality of the data for both of the variables was done by the researcher. The data were analyzed by using the formula of Liliefor's. The result of normality test for vocabulary mastery data and writing data are described as follows:

Table 3

Result of Normality Test

\begin{tabular}{|c|c|c|c|}
\hline Variables & Lo & $\begin{array}{c}\text { Lta } \\
\text { b }\end{array}$ & $\begin{array}{c}\text { Criteri } \\
\mathbf{a}\end{array}$ \\
\hline $\begin{array}{c}\text { Vocabulary } \\
\text { Mastery }\end{array}$ & 0,101 & 0,140 & Normal \\
\hline Writing & 0,10 & 0,14 & Normal \\
\hline
\end{tabular}

The table above, show that Lobserved of vocabulary mastery data was 0,10108 and Lobserved of writing data was 0,1011 . The result above, was showed that Lobserved was smaller than Ltable which mean that the data of vocabulary mastery and writing has normal distribution.

After the researcher conducted the normality test, the researcher continued to conduct the homogeneity test in order to know whether the data were homogeneous or not. In this research, the calculation of homogeneity test was done using Bartlett formula with level of significant scale $5 \%$ and df was 7. Then, the result of 
homogeneity test for both of data which is vocabulary mastery and writing data resulted $\chi_{\text {count }}^{2}$ was smaller than $\chi^{2}$ table . Therefore, it can be concluded that the variance of vocabulary mastery and writing data were homogeneous or had the same variant. The summary of the homogeneity calculation result for both of the instruments, can be seen as follows:

Table 4

Result of Homogeneity Test

\begin{tabular}{|c|c|c|c|}
\hline Variables & $\chi_{\text {coun }}^{\mathbf{2}_{\text {co }}}$ & $\chi^{\mathbf{2}}{ }_{\text {tabl }}$ & Criteria \\
\hline Vocabular & 8,71 & 14,0 & Homogeneou \\
y Mastery & & 67 & $\mathrm{~s}$ \\
\hline Writing & 6,22 & 14,0 & Homogeneou \\
& & 67 & $\mathrm{~s}$ \\
\hline
\end{tabular}

In this research, after the researcher having found the data were in normal distribution and homogeneous. Then, it was continued by calculating the hypothesis test. The hypothesis test was analyzed by using the formula of Product moment. From the result of the calculation, it is known that the value $r_{\text {observed }}$ or $r_{x y}$ by using the formula of Pearson Product Moment Correlation is 0,97 . Then, the value above, was compared with the value $r_{\text {table }}$ with $\mathrm{n}=40$ and significance level $\alpha 0,05$ and resulted the value of $r_{\text {table }}$ was 0,312 . Thus, it can be concluded that $\mathrm{H}_{0}$ is rejected and $\mathrm{H}_{a}$ is accepted because $r_{\text {observed }}$ was higher than $r_{\text {table }}$. Therefore, there is correlation between vocabulary mastery and students' achievement in writing descriptive text at the eighth graders of SMP Negeri 3 Kotabumi in academic year 2020/2021. The summary of the hypothesis test calculation can be seen as follows:

Table 5

The Summary of Hypothesis Test Result

\begin{tabular}{|c|c|}
\hline$r_{\text {observed }}$ & 0,977 \\
\hline$r_{\text {table }}$ & 0,312 \\
\hline
\end{tabular}

Having done the hypothesis test, it was continued by conducting the significance test. In this research, the researcher used the formula of t-test to know the significance between the variables. The summary of the significant test calculation can be seen as follows:

Table 6

The Summary of Significant Test

\begin{tabular}{|c|c|}
\hline$t_{\text {observed }}$ & 28,24 \\
\hline$t_{\text {table }}$ & 2,027 \\
\hline
\end{tabular}

From the result of the calculation above, It was gotten that $t_{\text {observed }}$ was 28,24 and $t_{\text {table }}$ was 2,027 which showed $t_{\text {observed }}$ is higher than $t_{\text {table }}$. Based on the statistic result it can be interpreted that vocabulary had high contribution toward 
students' writing achievement in descriptive text because the statistic result showing significant value.

Thus, it can be concluded that the correlation between vocabulary mastery and students' achievement in writing descriptive text at the eighth graders of SMP Negeri 3 Kotabumi in academic year 2020/2021 was significant. Therefore, the result of this research can be applied to all of the population in the research.

\section{Discussion}

Based on the calculation above, it was found that there is significant correlation between vocabulary mastery and students' achievement in writing descriptive text at the eighth graders of SMP Negeri 3 Kotabumi in academic year 2020/2021. Then, it was known that vocabulary mastery contributed about $95,45 \%$ to the students' achievement in writing descriptive text which show vocabulary mastery plays important role in the process of writing descriptive text and students' writing achievement. This result of the research is relevant with the theory from Thornburry (as cited in Setiani, 2018, p. 34) "without mastery the grammar in writing process very little can be conveyed. However, without vocabulary nothing can be conveyed."

Referring to the theory, it is clear that vocabulary mastery is the most important aspect that should be mastered first before the students want to write something easily. They cannot produce a good writing text if they do not know many vocabularies. Commonly, the students will get the difficulties in writing process if they do not master the vocabulary well. Thus, vocabulary mastery is very crucial in determining the students' achievement in writing descriptive text.

In addition, the result of this research also in line with two previous related research. The first research was conducted by Rahmati (2018) from State Islamic University of Ar-raniry Banda Aceh, with the title "The Correlation between Vocabulary Mastery and Students' Writing Skill" and another research was conducted by Azizah (2017) from State Institute for Islamic Studies of Salatiga, with the title "The Correlation between Students' Vocabulary Mastery and Their Writing Ability in Descriptive Text". Those two previous researchs also have the same result that found there was correlation between vocabulary mastery and students' writing skill.

Based on the explanation, data analysis, supporting theories, and previous research above, it can be concluded that vocabulary mastery becomes the most important aspect to support the students' achievement in writing descriptive text. Therefore, the students are supposed to be 
The Correlation Between Vocabulary Mastery and Students' Achievement in Writing Descriptive Text at The Eighth Graders of Smp Negeri 3 Kotabumi in Academic Year 2020/2021

(Usi Ismayanti, Rini Susilowati)

able have good vocabulary mastery to enhance their writing achievement because the more vocabularies that students have the more opportunities they can produce a good writing and get a good achievement in writing descriptive text and learning process.

\section{CONCLUSION}

After the researcher getting the data that have been analyzed in the previous chapter, the researcher concluded that there is significant correlation between vocabulary mastery and students' achievement in writing descriptive text at the eighth graders of SMP Negeri 3 Kotabumi in Academic Year 2020/2021. From the result of the previous chapter, it can be said that if the students mastering a lot of vocabulary, they will also have a good achievement in writing a descriptive text.

\section{REFERENCES}

Azizah, Yuyun. (2017). The correlation between students' vocabulary mastery and their ability in writing descriptive text at the seventh grade students of SMP Islam Sudirman 1 Bancak Semarang District in academic year 2016/2017. Script Unpublished. Salatiga: State Institute for Islamic Studies Salatiga.

Brown, H. Douglas. (2004). Language assesment: Principles and classroom practices. NewYork: Longman.

Creswell, John W. (2012). Educational research: Planning, conducting, and evaluating quantitative and qualitative research $4^{\text {th }}$ edition. Buston: Pearson Education.

Hasan., \& Subekti, N. B. (2017). The correlation between vocabulary mastery and writing skill of secondary school students. Journal of English Language and Language Teaching (JELLT), 1(2), 55-60. http://jurnal.ustjogja.ac.id

Hidayati, Kuni Hikmah. (2018). Teaching writing to EFL learners: An investigation of challenges confronted by Indonesian teachers. Langkawi Journal of The Association for Arabic and English, 4(1), 21-31. http://ejournal.iainkendari.ac.id

Hornby, A. (2010). Oxford advanced dictionary. New York: Oxford University Press.

Husna, Lailatul., Zainil., \& Yeni, Rozimela. (2013). An analysis of students writing skill in descriptive text at the grade XI IPA 1 of MAN 2 Padang. Journal English Language Teaching, 1(2), 1-16. http://ejounal.unp.ac.id

Khumaedi, Muhammad. (2012). The Reliability of Education Research Instruments. JPTM, 12(1), 25-30. http://www.journal.unnes.ac.id 
Longman. (2001). Dictionary of contemporary english. Harlow: Pearson Education Limited.

Pardiyono. (2006). 12 writing clues for better writing competence. Yogyakarta: ANDI

Porter, David. (2001). Check your vocabulary for english for academic purposes: A workbook for users. London: A\&C Black Publisher.

Rahmati, Umairah. (2018). The correlation between vocabulary mastery and students' writing skill a study at English Department of UIN Ar-raniry. Script Unpublished. Banda Aceh: State Islamic University of Ar-raniry.

Riswanto, Ari., \& Aryani, Sri. (2017). Learning motivation and students achievement: Description analysis and relationships both. International Journal of Counseling and Education, 2(1), 42-47. http://www.researchgate.net

Setiani, Rulik. 2018. The implementation of lesson study to improve students' vocabulary mastery through team accelerated instruction (TAI). Journal Elsa, 16(1), 33-38. http://jurnal.umko.ac.id

Susilowati, Rini. 2018. Instruction as influential factors toward the rate of children in learning english vocabulary. Journal Elsa, 16(2), 36-45. http://jurnal.umko.ac.id

Ur, Penny. (2009). A course in language teaching. UK: Cambridge University Press. 